\title{
The Role of Environment, Business and Human Behavior towards Entrepreneurial Sustainability
}

\author{
Nadia A. Abdelmegeed Abdelwahed ${ }^{1}\left(\mathbb{D}\right.$, Bahadur Ali Soomro ${ }^{2, *}\left(\mathbb{D}\right.$ and Naimatullah Shah ${ }^{3}$ \\ 1 Department of Business Management, College of Business Administration, King Faisal University, \\ Al Hofuf 31982, Saudi Arabia; nabdelwahed@kfu.edu.sa \\ 2 Department of Economics, Abdul Haq Campus, Federal Urdu University of Arts, Science and Technology, \\ Karachi 75300, Pakistan \\ 3 Department of Public Administration, University of Sindh, Jamshoro 76080, Pakistan; \\ naimatullah.shah@usindh.edu.pk \\ * Correspondence: bahadur.ali@scholars.usindh.edu.pk; Tel.: +92-3337235996
}

Citation: Abdelwahed, N.A.A. Soomro, B.A.; Shah, N. The Role of Environment, Business and Human Behavior towards Entrepreneurial Sustainability. Sustainability 2022, 14, 2517. https://doi.org/10.3390/ su14052517

Academic Editors: Fernando Almeida and Marc A. Rosen

Received: 28 November 2021 Accepted: 8 February 2022

Published: 22 February 2022

Publisher's Note: MDPI stays neutral with regard to jurisdictional claims in published maps and institutional affiliations.

Copyright: (C) 2022 by the authors. Licensee MDPI, Basel, Switzerland. This article is an open access article distributed under the terms and conditions of the Creative Commons Attribution (CC BY) license (https:// creativecommons.org/licenses/by/ $4.0 /)$.

\begin{abstract}
The current paper investigates the factors, i.e., environmental, business, behavioral, and human relations, that promote entrepreneurial sustainability of SMEs in Pakistan. The study employs the quantitative approach, which utilizes the cross-sectional data of 347 entrepreneurs of the SMEs sector of Pakistan. The data study applies a survey questionnaire to collect the data. The random technique is employed to target the respondents. By employing the structural equation model (SEM), the study finds a positive and significant impact of environment/surroundings, business, behavior, and human-related factors on entrepreneurial sustainability. In a simple sense, all the hypotheses are accepted. The study's findings would encourage practitioners, researchers, and policymakers to hunt the patterns of social, behavioral, economic, human, and environmental contributions to promote entrepreneurial activity. Further, the study would provide an optimal solution to utilize these factors for bringing sustainable development SMEs.
\end{abstract}

Keywords: entrepreneurial sustainability; optimal solution; environmental management; business environment; SMEs

\section{Introduction}

In today's world, entrepreneurship is a reliable source to overcome the economic and sustainability challenges [1-9]. The various frameworks of sustainability have set out millstone development in both conceptual and empirical research with different perspectives during the years. According to Cohen and Winn [4], sustainable entrepreneurship remained the magnifier of broad welfares and moved ahead of the significance of how "future goods and services are discovered, created, and exploited, by whom, and with what economic, psychological, social, and environmental consequences". Sustainable entrepreneurship is an entrepreneurial action employed for improvement of the environment. Such progress brings social well-being and generates profits [10]. The protagonist goal of sustainable entrepreneurship is to initiate actions and developments that create profitable opportunities and contribute to sustainable development [11]. In the same aspect, sustainable entrepreneurship can be associated with pro-social behavior and entrepreneurial movements' orientation to make available paybacks to other people [2]. However, it is a challenging and complicated process to bring sustainable development among business people/entrepreneurs [12]. Besides, there are few studies about entrepreneurial as concentrated on an investigation of the people's entrepreneurial mental function, including the level of intention/propensity.

The relevant literature on developed economies demonstrates remarkable attention to the limitations of entrepreneurial dynamics in developing countries $[13,14]$. As small and medium enterprises (SMEs) are essential pillars of an economy, a progressing and booming 
SME sector supports an economy in overcoming macro-economic and entrepreneurship sustainability problems. Due to SMEs' prominent share in bringing remarkable achievement in entrepreneurship process and an engine of growth, limited research has been conducted in entrepreneurship sustainability in SMEs [15].

The current economic circumstances do not remain in favor of business in Pakistan [16]. Therefore, more investigation is required in the perspective of entrepreneurship sustainability that remains a significant challenge, particularly in the SMEs context, despite substantial economic stability and well-being $[16,17]$. The current study aimed to explore the factors that affect entrepreneurial sustainability in small and medium-sized enterprises in Pakistan. The study may serve as a preliminary step to recognize SMEs owner-managers' cognitive process in embarking on sustainable entrepreneurship. The study would bring new insights and importance of the environmental, business, and behavioral factors towards carrying the robust sustainability among SMEs of developing economies. Besides, the study would enrich the literature and support the scholars in developing the theories and innovative ideas regarding sustainable entrepreneurship through improving environmental, business, and behavioral intentions through better human relations.

\section{Literature Review}

Broadly, sustainable entrepreneurship is necessary for the well-being and the development of infrastructure and the economic growth of the economies. In Tachiwou [18] perception, faster development of infrastructure is a requirement of a fast-growing economy. According to Koe et al. [19], perceptual factors (i.e., perceived feasibility and perceived desirability) and attitudinal factor (i.e., sustainable attitude) are the significant factors which make a person's level of propensity promptly to sustainable entrepreneurship. Among the Spanish entrepreneurs, facilitating conditions; effort and performance expectancy; hedonic motivation; social influence; and behavioral intentions positively and significantly affect the sustainable business model innovation [20]. Sarabia et al. [21] propose that entrepreneurship's conflict constructs are not successful initiatives to attain a sustainable merger practice over time. In the perception of Uhlaner, Brent, and Jeurisse [22], firms with a more pioneering orientation have more preference towards establishing sustainable entrepreneurship behaviors. The crucial performance catalogues and level of growth of an organization are the processes of business achievement. They are triggering predictors including motivation and personality that push entrepreneurs into making effort a thoughtful cap on one hand and increasing predictors including education level (formal and informal) and management skills, as explained, vital to entrepreneurial success. There is a significant association of personality characteristics; motivating factors; management skills and capacities; and environmental forces with the level of entrepreneurial success [23]. Direct support of government towards SMEs is active in escorting the sector's development and growth [24]. The existence of a significant and positive association between entrepreneurial levels of support, as demonstrated by family support, and entrepreneurial success, investigated by [25]. In South Africa, global trade brings sustainable development through business practices and entrepreneurship [26].

In the Arab world, female business students are endeavoring to engage in entrepreneurial activities. The education system supports providing a conducive educational environment [27]. According to Ben Mahjoub and Amara [28], shareholder governance significantly predicts environmental sustainability through the moderation of culture. In Saudi Arabia, the individual factors, i.e., social legitimacy, financial resources, and entrepreneurial personality, increase the entrepreneurial competencies. Besides, education, gender, fear of failure, and income are the significant developers of a business startup [29]. Similarly, social media has also had a substantial effect on the development of SMEs in the Arab world [30,31]. In the Middle East and North Africa (MENA) region, gender and female entrepreneurial behavior significantly predict entrepreneurship [32].

Thus, developing sufficient sustainability abilities, such as creating an optimistic or promising sustainability attitude and generating attractive, hence, sustainable, entrepreneurial 
practices, is responsible for promoting sustainable entrepreneurship. Therefore, sustainability culture is significantly associated with all the methods and entrepreneurial orientation effects. It moderates the social sustainability culture only in the growing social sustainability and supply chain practice acceptance [33]. The certain traits of the entrepreneur, including education and work experience, have a substantial influence on sustainable entrepreneurship. Besides, customer orientation and environmental factors and human resources are the most essential for SMEs' durable performance [34]. By collecting the primary data from chief executive officers/entrepreneurs, Amankwah-Amoah et al. [35] found an indirect correlation between entrepreneurship orientation and new venture performance.

SMEs have a crucial role in upgrading the economy through industrial development. Due to this reason, up to $98 \%$ of enterprises have been developed in Europe. These create more than half of the employment opportunities in the European Union [36]. Further, SMEs established the mainstream of enterprises in developing countries and are explained as one of the most significant predictors in social and economic growth, local development and employment [37], and poverty alleviation [38]. In Northern Thailand, small and medium enterprises (SMEs) (agro-food processing industries, vegetables and fruit processing industries, and meat processing industries) have a noteworthy contribution towards sustainable development [39]. Recently, Ukko et al. [40] investigated a vital role of sustainability factors in small business. The findings of the study found a predictive effect of sustainability on the intention to exploit open sustainability. However, the results did not confirm the impact of company size on the use of open sustainability. According to Davies [41], social-economic activities related to the environment have a tremendous role in enterprises' sustainable development and sustainability.

As the most growing reputation of the SMEs, many scholars have concentrated on the problems associated with its growth. Hence, it has become the core theme for many analyses. On the other side, the existing research review underlines that the academic literature on sustainable entrepreneurship has grown-up meaningfully over the last few decades [4,6]. Saqib et al. [42] suggest that ABES-TEC had to attempt self-sustainability rather than arbitrary project funding to retain employees in Pakistan. In the perception of Kuckertz and Wagner [6], the critical literature on the sustainability of entrepreneurship has often concentrated on entrepreneurship's environmental features $[3,43]$. The effect of socioeconomic status, personality characteristics, and religion on SE has all been regarded as unpredictable [44]. According to Gasbarro et al. [45], sustainable institutional entrepreneurs (SIEs) have developed inventive business models from direct association with the final customers and strategic partnerships for growing acceptability within the normative and cultural-cognitive organizations. Sustainability education and sustainability orientation predict green entrepreneurship inclination, especially among the youth [17]. In a similar vein, the demographic factors substantially affect entrepreneurial performance [46]. Besides, Hall et al. [13] proposed the existence of methodologies of sustainable entrepreneurship. A shortage of academic research and publications demands more investigation and the potential expansion of the area, such as a comprehensive analysis, mostly concentrated on only one perspective (the environmental or social pillars). Thereby, investigators ignore the productive potential of this particular field of study. Highlighting the importance of such an area, Young and Tilley [47] stressed that specific goals are increased from the "whole enterprise design" by integrating social, economic, and environmental mechanisms of sustainability within the organizational policy. However, a few investigations in social studies, environmental management, and wide-ranging business offer the illustrations of undertaking towards the enlargement of enterprise in sustainability; academic exploration concerning an amalgamation of sustainable development; and entrepreneurship moderately budding - the factors such as the perceived entrepreneurial desirability and attitude toward sustainability increase sustainability-oriented entrepreneurial intentions. Besides, attitudes toward sustainability are absolutely and significantly influenced by altruism, although the perceived entrepreneurial desirability is determined by intrinsic and extrinsic rewards [48]. 
The freshness of the field delivers more excellent prospects to determine new bases and associations in sustainable entrepreneurship in SMEs [49]. This is essential to the reminder that when it comes to the performance of SMEs in seeking sustainable development, it is apparent that SMEs have mostly been unnoticed [50]. As a result, the literature shares overwhelming attention on developed economies and has restricted our thoughtfulness about developing countries' entrepreneurial dynamics [13]. In Pakistan's context, SMEs are confronting ever-increasing competition at both domestic and the global level despite a substantial contribution towards economic competitiveness and development, innovation, and, even in the future, growth [51,52].

\section{Conceptual Framework and Hypotheses Development}

Sustainable entrepreneurship is a suitable pledge toward overall well-being. In other research tasks, the concept is predicted and promoted through the various factors including business, social factors, economic and social factors, behavioral factors, and human relation factors $[53,54]$. The past research found a wide-ranging outlook of organizational sustainability that highlights three aspects: social sustainability; economic prosperity; and environmental integrity $[54,55]$. Such factors refer to financial strength, environmental preservation that is essential to protect the environment and the needs of the next generation, and ensure the social health and well-being of an organization's associates [54]. Henceforth, sustainable entrepreneurship is an integrated approach that involves economic factors, such as product competitiveness and profits, enablers associated with the conservation of the environment and its surroundings, and the social factors that denote individuals' health and well-being. Instantaneously, through an objective of refining the environment and progressing social prosperity, sustainable entrepreneurship can also affect structural social changes and stimulate sustainable equipment connected with such sustainable creativities [53].

Sustainable entrepreneurship can be driven by the business factors, which are comprised of profit generated by the economic activity [53], job satisfaction indicated by individuals' extent of comfort with the work milieu and how they embrace pay, and work type, as well as the security of job [55]. Metacognition, motivation, and lifestyle are significant factors of behavior. These factors reflect the capacity of the individuals in the way of the learning [56] of emotional self-regulation processes [57] to perform entrepreneurial tasks [58]. Lastly, lifestyle refers to how an individual apprehends and lives his or her life. It is self-sacrifice, which mentions anxiety for others (as contrasting to selfishness) and the propensity to pursue the best consequence [59].

Likewise, human relations factors are associated with the channels through which people relate to one another. These factors are responsible for emerging a significant standing among others near the entrepreneur and ordinary people, confirming correspondence between enterprise goals and developing trustworthy relations with workers, and merging the individual and collective leadership [10]. Through the leadership domain of human relations, the leader exclusively encourages others by commendably accomplishing projects, while unification of this sort of leadership is a collaborative and evolving process, where people embolden one another to attain collective and organizational targets, which can stimulate members to perform entrepreneurial ways [58,60].

As a result, these factors have been used earlier in different contexts including Spain [10], Finland and Germany [61], and the US [53]. More incredible projections regulate new bases and relations in sustainable entrepreneurship in SMEs [49]. It is indispensable to notice that when it comes to the performance of SMEs in considering sustainable development, it turns out that SMEs have mostly been overlooked [50]. There is a low reflection of entrepreneurial dynamics [13]. However, in the SMEs sector of Pakistan, such factors have not been yet investigated due to a considerable influence on economic development, competitiveness, innovation, and future growth [51,52].

Realizing the relevant factors, the study's conceptual model was developed by the environmental factors including the business factors, behavior, and human relations. The 
environment/surrounding elements submerged into sub-factors, including environmental sustainability, social awareness, policies, and environmental regulations. It is well thought-out as a deficiency of resource and capability of the environment to tolerate human management [62]. Similarly, the business factors included effective business, profit, job satisfaction, and subsidies [54,63,64].

More specifically, it is inconsistent with previous research on sustainable entrepreneurship the researchers included environmental, business, behavioral, and human relations constructs to examine the entrepreneurship sustainability (Figure 1). The object of the study was to investigate the key factors that have a positive role in bringing out sustainable entrepreneurship among SMEs in Pakistan.

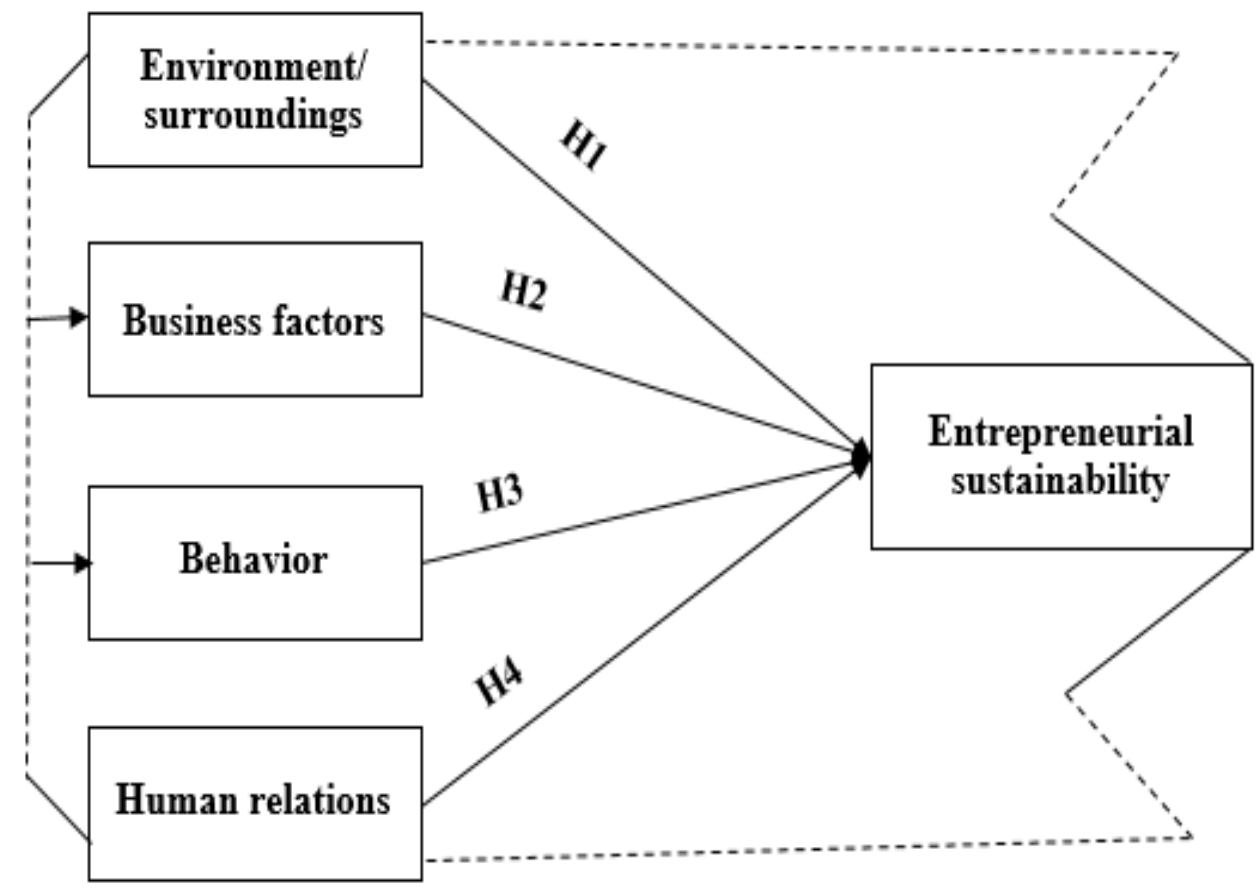

Figure 1. Conceptual model of the study.

The literature offers the base of organizational sustainability on three main factors, i.e., environmental integrity, social sustainability, and economic prosperity [54,64]. Environmental integrity is about environmental safety, which is essential to protect the environment and essentials of future generations. Similarly, social sustainability covers the developments that safeguard social health and the well-being of the associates of an enterprise [54]. Sustainable entrepreneurship is a multifaceted notion promoted through economic factors (product competitiveness, profits and so on) and environment and surroundings. These factors are accountable for the safety, well-being and prosperity of the people. Simultaneously, through its objectives of refining the environment and progressing social welfare, sustainable entrepreneurship can also impact socio-structural revolutions and enhance the sustainable technologies related to the sustainable creativities $[53,61]$. Thus, it can deliver social and economic resolutions for transmuting and directing entrepreneurial inventiveness towards sustainability. Hence, it reveals sustainable entrepreneurship and the necessity to recognize factors that inspire sustainable entrepreneurship. The elements, including compassion, empathy, altruism, ethics, and economic profits, are significant factors that form the base of sustainable entrepreneurship [65]. The company's profitability may contribute to sustainability [7].

The three categories of behavioral and human relations factors consist of emotional factors; cognitive and motivational factors; and values and ethics influencing sustainable entrepreneurship. Entrepreneurs have entrepreneurial inspirations, which connect to innovations and the misuse of opportunities through working arrangements [66]. Entrepreneurs 
have the necessary human capital to obtain and transform evidence [60]. Furthermore, entrepreneurs have a delicate perception of self-efficacy and belief in themselves, realizing that the ability to accomplish their objectives and characteristics becomes the source of their successes and failures [58]. According to Hall et al. [13], dynamic entrepreneurs are apprehending market inadequacies; consequently, they vigorously assist institutional creativities that intend to promote sustainable practices.

The reliance on promoting sustainability is narrowly associated with individual ethics and values. Such factors have a significant position in the enlargement of behaviors and the mode in which sustainable activities are commenced. Meek et al. [67] proposed that the values were inclined to be individual, and adopted under culture and society. The patterns in which individuals behave are likely to be steady with their values. As a result, such behaviors bit by bit become social norms. Social norms accompanied by governmental inducements easily direct sustainability and sustainable entrepreneurship. Sustainable entrepreneurship is hugely affected by culture and society [68] where emotions have a crucial role in distressing entrepreneurial individuals and business actions. The capability to handle failure is connected to real passions as submerged into gladness, affection, and eagerness. Meanwhile, the positive feelings help individuals convalescing from hindrances by navigating the undertaking along a more successful way and intensifying their determinations. In brief, the researchers have presented the prominence of emotional self-regulation in entrepreneurship practices, in which entrepreneurs must respond to a chain of obstacles, which can substantiate repulsively [57].

As a result, the literature, as mentioned above, clearly demonstrates an investigation in which a positive and significant association of business factors, environment/surroundings, behavior, personality, motivational, and human relations factors exists with sustainable entrepreneurship in the different contexts of Europe and Asia [53,60]. However, such a type of study was not carried out in Pakistan, as found in the area of sustainable entrepreneurship, particularly in SMEs. From these associations, we proposed the following hypotheses for examination in SMEs of Pakistan:

Hypothesis 1 (H1). Environment/surroundings (environmental sustainability, social awareness, policies, and environmental regulations) have a positive and significant impact on entrepreneurial sustainability.

Hypothesis 2 (H2). Business factors (profits, job satisfaction, business management, and access to subsidies) have a positive and significant impact on entrepreneurial sustainability.

Hypothesis 3 (H3). Behavior (prosocial, intrinsic, extrinsic, and flow) has a positive and significant impact on entrepreneurial sustainability.

Hypothesis 4 (H4). Human relations (reputation, congruence, and leadership) have a positive and significant impact on entrepreneurial sustainability.

\section{Research Methods}

\subsection{Data Collection and Sample}

We contacted 622 Pakistani SMEs to participate in a survey about the factors that may affect sustainable entrepreneurship. To this regard, the SMEs selected were due to their playing an active role in developing economy by making many business accomplishments, or sustainable management, profit generation, and sustainability development [19]. A closed-ended survey questionnaire was employed to obtain a response from the participants. We adopted two modes of data collection covered through individual visit and email with the random sampling technique's support to trace out the participants. Thus, questionnaires were sent to the entrepreneurs' email and individual visits were conducted after primarily getting their consent regarding the survey's participation. We collected the data between April 2018 and October 2018. Upon acceptance, the entrepreneurs completed a survey questionnaire (business possessors treated as key informants who started sustainable businesses in different SMEs sectors) (Table 1). In return, 347 questionnaires 
were received back with a response rate of about $55 \%$. We attempted to choose more closely related respondents to the population to ensure the survey's ability. Therefore, collecting data from both males and females reduces the gender bias and re-presentation of samples. Besides, the responses from 347 SMEs represent generalization of SMEs. Therefore, the collected data would match with key characteristics in the entire population of top managers. Using a sample of participants that are representative of the population is vital for generalizing from a sample to the population. In this way, the distribution of 622 questionnaires among 14 leading SMEs through probability sampling would provide generalizations of population and re-presentation.

Table 1. SMEs and sample.

\begin{tabular}{clccc}
\hline S.No. & SMEs & Questionnaires Sent & Questionnaires Received & Responses Rate $\%$ \\
\hline 1 & Rice husking & 45 & 25 & 55.55 \\
\hline 2 & Cotton ginning & 50 & 24 & 48 \\
\hline 3 & Power looms & 44 & 24 & 50.90 \\
\hline 4 & Dairy and livestock & 48 & 20 & 58.82 \\
\hline 5 & Cutlery and stainless Utensils & 34 & 28 & 66.66 \\
\hline 6 & Surgical instruments & 42 & 16 & 50 \\
\hline 7 & Marble and granite & 32 & 44 & 80 \\
\hline 8 & Engineering goods, (electronic) & 55 & 27 & 58.69 \\
\hline 9 & Packaging/processing of & 46 & 18 & 45 \\
\hline 10 & Fruits/vegetables & & 12 & 37.5 \\
\hline 11 & Firniture & 40 & 32 & 69.56 \\
\hline 12 & Gems and jewelry & 32 & 33 & 66 \\
\hline 13 & Sports goods & 46 & 26 & 44.82 \\
\hline 14 & Agro-based industry & 50 & 347 & \\
\hline
\end{tabular}

\subsection{Measures}

The study dove into the environment, business, behavior, and human relations factors responsible for bringing sustainable entrepreneurship in an economy.

The environment factors: the environment/surroundings factors were grouped into four sub-domains. These domains include " $1=$ environmental sustainability; 2 = social awareness; 3 = policies; and $4=$ environmental regulations". The area of sustainability refers to resource efficacy and the environment's capability to tolerate human management [69]. The social awareness, as taken from education, which happens within society, promotes cognizance of the advantages and disadvantages of environmental education. Similarly, policies are comprised of organizational and institutional initiatives planned to encourage entrepreneurship. Lastly, environmental regulations assure compliance with the relevant legislation. Such items were taken from the empirical work of Tur-Porcar et al. [10]. We employed a five-point Likert scale to measure out the elements starting from very untrue $=1$; untrue $=2$; neither untrue; nor true $=3$; true $=4$; and very true $=5$.

Business factors: the business factors were comprised of sub-factors. These factors include " $1=$ profits; $2=$ job satisfaction; $3=$ business management; and $4=$ access to subside". The profits are produced by economic activity [54]. Job satisfaction points to the extent of satisfaction of individuals with the work environment and covers pay, work criterion, and job security [55]. Hence, efficient business management is about the planning, management, organization, and control of the organization's resources for maximizing economic profit and social benefit $[63,64]$. However, access to subsidies is about receiving 
subsidies, support, and counseling services from both public and private organizations. Such items/sub-factors were adapted from the study of Tur-Porcar et al. [10]. We applied a five-point Likert scale ranging from very untrue $=1$; untrue $=2$; neither untrue; nor true $=3$; true $=4$; and very true $=5$ to get the respondents' responses.

Behavior: this factor is divided into three sub-factors, including motivation, lifestyle, and metacognition. The motivation factor consisted of four sub-factors including "prosocial $=1$; intrinsic $=2$; extrinsic $=3$ and flow $=4$ ". Similarly lifestyle was comprised of four sub-factors including "altruism $=1$; compassion $=2$; empathy $=3$ and ethics $=4$ ". Lastly, metacognition also consisted of three sub-factors, such as "self-regulation $=1$; self-efficacy $=2$ and competitive intelligence $=3$ ". We adopted items from the study of Tur-Porcar et al. [10]. We employed a five-point Likert scale based on choices as very untrue $=1$; untrue $=2$; neither untrue; nor true $=3$; true $=4$; and very true $=5$ to assess the items/sub-factors.

Human relations: this factor also consists of three sub-factors. These include "reputation $=1$; congruence $=2$ and leadership $=3^{\prime \prime}$. Such items $/$ sub-factors were adapted from the study by Tur-Porcar et al. [10]. We applied a five-point Likert scale ranging from very untrue $=1$; untrue $=2$; neither untrue; nor true $=3$; true $=4$; and very true $=5$ to assess the items/sub-factors.

Sustainable entrepreneurship: this factor was assessed based on three sub-domains. These domains include "people $=1$; planet $=2$ and business performance $=3$ ". The items for the element were adapted from Soto-Acosta et al. [64]. All items were assessed by examining the choices on a five-point Likert scale (very untrue $=1$; untrue $=2$; neither untrue; nor true $=3$; true $=4$; and very true $=5$ ).

We ensured the reliability of the survey through Cronbach's alpha $(\alpha)$ reliability. We noted the overall reliability of the survey as 0.842 . Further, business factors $(0.820)$, environmental (0.876), human relations (0.807), behavior (0.797), and entrepreneurial sustainability appeared with 0.865 .

\section{Statistical Analysis and Results}

\subsection{Respondents' Profile}

The demography of the respondents highlighted was about $60 \%(n=210)$ male figures, while $39 \%(n=137)$ of the participants were female figures (Table 2$)$. The majority of respondents $(42 \% / n=147)$ were between $26-35$ years of age. In total, $33 \%(n=116)$ of the respondents were between 36-45 years of age. Hence, the minority of respondents were between $18-25$ years of age. Similarly, $46 \%(n=161)$ have a Masters degree in education; $39(n=136)$ have passed their bachelor's degree. Hence, respondents had the background of primary, HSC, and diploma, and M.Phil and PhD degrees were found in a limited number (Table 2).

Table 2. Respondents' profile.

\begin{tabular}{cccc}
\hline Demographic Variables & Category & Frequency & Percent \\
\hline \multirow{3}{*}{ Gender } & Male & 210 & 60.51 \\
& Female & 137 & 39.49 \\
& Total & 347 & 100.0 \\
\hline \multirow{4}{*}{ Age } & $18-25$ & 4 & 11.53 \\
& $26-35$ & 147 & 42.36 \\
& $36-45$ & 116 & 33.43 \\
& Over 45 & 44 & 12.68 \\
& Total & 347 & 100.0 \\
\hline \multirow{4}{*}{ Level of education } & Primary-HSC level/diploma etc. & 40 & 11.53 \\
& Bachelor degree & 136 & 39.19 \\
& Master degree & 161 & 46.39 \\
& M.Phil./Doctoral degree & 10 & 2.89 \\
& Total & 347 & 100.0 \\
\hline
\end{tabular}




\subsection{Descriptive Statistics}

At the initial stage, we computed descriptive statistics to get the necessary information about the population through inferential statistical tests. We found the mean scores to be between 3.220 and 3.801. Likewise, the standard deviation values were also observed between 1.020 and 1.101 (Table 3).

Table 3. Descriptive statistics.

\begin{tabular}{lcc}
\hline Variables & Mean & Std. Deviation \\
\hline 1. Entrepreneurial sustainability & 3.567 & 1.108 \\
2. Environmental/surroundings & 3.220 & 1.020 \\
3. Business factors & 3.567 & 1.101 \\
4. Behavior & 3.689 & 1.076 \\
5. Human relations & 3.801 & 1.070 \\
\hline
\end{tabular}

\subsection{Measurement Model}

We measured the degree of multiple items (convergent validity). To achieve this, three main aspects, i.e., the loadings, average variance extracted, and composite reliability, are observed based on suggested values as loadings $>0.5$, AVE $>0.5$, and CR $>0.7$ for a good convergent validity. As a result, we found loading scores $>0.7$, the AVE $>0.7$ and the composite reliability for each construct is noted to be $>0.7$; henceforth, convergent validity was confirmed (Table 4).

Table 4. Measurement model.

\begin{tabular}{lcccc}
\hline Construct & Item & Loadings & AVE & CR \\
\hline \multirow{4}{*}{ Environment/surroundings } & en4 & 0.896 & & \\
& en1 & 0.875 & 0.878 & 0.768 \\
& en3 & 0.860 & & \\
en2 & 0.824 & & \\
Business factors & bf2 & 0.883 & & \\
& bf1 & 0.845 & 0.890 & \\
\hline & bf4 & 0.832 & & \\
bf3 & 0.801 & & \\
Behvaiour & mo4 & 0.840 & & \\
& mo2 & 0.826 & & \\
mo3 & 0.810 & & \\
& mo1 & 0.789 & & \\
Is2 & 0.771 & & \\
Is4 & 0.770 & 0.856 & \\
Human relations & Is1 & 0.768 & & \\
& Is3 & 0.756 & & \\
\hline & mn1 & 0.740 & & \\
\hline
\end{tabular}


Table 4. Cont.

\begin{tabular}{ccccc}
\hline Construct & Item & Loadings & AVE & CR \\
\hline & pe2 & 0.876 \\
pe1 & 0.870 \\
Entrepreneurial sustainability & pe3 & 0.867 & & \\
& pl1 & 0.852 & & \\
& pl2 & 0.843 & 0.807 & 0.825 \\
& pl3 & 0.832 & & \\
& bp3 & 0.820 & & \\
\hline
\end{tabular}

AVE-average variance extracted, CR-composite reliability.

Furthermore, we measured the degree to which items differentiate among constructs or measure distinct concepts (discriminant validity) through inspecting the correlations between the measures of possibly overlapping constructs. According to scholars, such as Compeau et al. [70] and Ramayah et al. [71], items must load more powerfully on their variable in the model. The average variance shared between each variable and its measures must be greater than the variance shared between the variables and other variables. In this, the observed values of the measurement model highlight adequate discriminant validity (Table 5).

Table 5. Discriminant validity.

\begin{tabular}{lccccc}
\hline \multicolumn{1}{c}{ Variables } & $\mathbf{( 1 )}$ & $\mathbf{( 2 )}$ & $\mathbf{( 3 )}$ & $\mathbf{( 4 )}$ & $\mathbf{( 5 )}$ \\
\hline 1.Entrepreneurial sustainability & $\mathbf{0 . 7 3 9}$ & & & & \\
2.Environmental/surroundings & 0.308 & $\mathbf{0 . 8 2 9}$ & & & \\
3.Business factors & 0.419 & 0.333 & $\mathbf{0 . 7 4 6}$ & & \\
4.Behavior & 0.522 & 0.122 & 0.198 & $\mathbf{0 . 7 5 8}$ & \\
5.Human relations & 0.369 & 0.339 & 0.234 & 0.4832 & $\mathbf{0 . 8 5 4}$
\end{tabular}

Note: Diagonals represent the square root of the average variance extracted while the other entries represent the correlations.

\subsection{Model Fitness and Hypotheses Confirmation}

The model governs good results since the goodness of fit indices fulfill all requirements of the statistics. The model's fitness indicators were noticed to ensure the strength of statistical tests. The model fit indices proposed non-significant values of $\chi 2 / C M I N$ (2.539; $p>0.005$ ) (Table 6) that demonstrated an indication of model fitness with available data $[72,73]$. To ensure further, we observed the relevant values of other model fit indices as CFI (0.978); AGFI (0.968); NFI (0.948); GFI (0.960); and RMSEA (0.040) (Table 6). Thus, the weights revealed a requirement of acceptance [73] as an absolute fit/good fit [74].

Table 6. Model fit indices.

\begin{tabular}{lcccccc}
\hline \multicolumn{1}{c}{ Model Fitness } & CMIN/df & GFI & AGFI & NFI & CFI & RMSEA \\
\hline Model fit indicators & 2.539 & 0.978 & 0.968 & 0.948 & 0.960 & 0.040 \\
Suggested values & $<3$ & $>0.90$ & $>0.90$ & $>0.90$ & $>0.90$ & $<0.05$ \\
\hline
\end{tabular}

Note: $\mathrm{CMIN}=\chi^{2} / \mathrm{Chi}$-square $/ \mathrm{df} ; \mathrm{df}=$ degree of freedom; $\mathrm{GFI}=$ goodness of fit index; $\mathrm{AGFI}=$ adjusted goodness of fit index; NFI = normed fit index; $\mathrm{CFI}=$ comparative fit index; RMSEA = root mean square error of approximation.

Additionally, we employed the structural equation model (SEM) to assess the factors' hypothesized paths' robustness. The outcomes of the SEM findings have underlined a positive and significant impact of environment/surroundings on entrepreneurial suitability (SE $=0.048 ; C R=5.342 ; p<0.01$ ) (Figure 2 and Table 7). Thus, H1 was accepted. Similarly, the business factors have a significant and positive impact on entrepreneurial suitability $(\mathrm{SE}=0.078 ; \mathrm{CR}=4.672 ; p \leq 0.01)$ (Figure 2 and Table 7). Therefore, $\mathrm{H} 2$ was supported. 


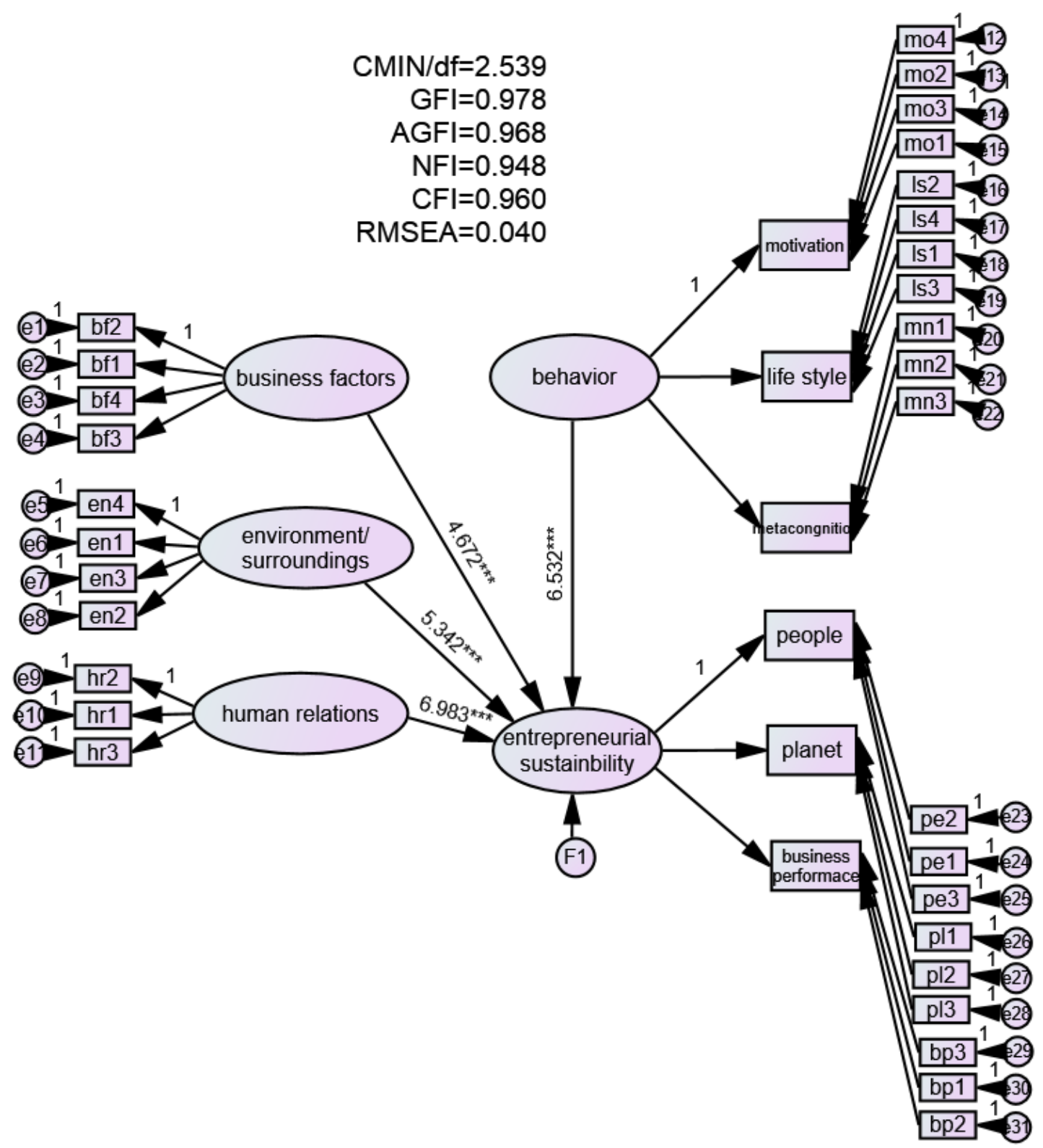

Figure 2. Structural equation model. (Note: ${ }^{* *} p<0.05$.)

Table 7. SEM estimations.

\begin{tabular}{|c|c|c|c|c|c|c|c|c|}
\hline H.No. & $\begin{array}{c}\text { Independent } \\
\text { Variables }\end{array}$ & Path & $\begin{array}{l}\text { Dependent } \\
\text { Variables }\end{array}$ & Estimate & SE & CR & $p$ & Decision \\
\hline 1 & $\begin{array}{l}\text { Environment/ } \\
\text { surroundings }\end{array}$ & $\rightarrow$ & $\begin{array}{c}\text { Entrepreneurial } \\
\text { sustainability }\end{array}$ & 0.346 & 0.048 & 5.342 & $* * *$ & Accepted \\
\hline 2 & Business factors & $\rightarrow$ & $\begin{array}{c}\text { Entrepreneurial } \\
\text { sustainability }\end{array}$ & 0.258 & 0.078 & 4.672 & $* * *$ & Accepted \\
\hline 3 & Behavior & $\rightarrow$ & $\begin{array}{c}\text { Entrepreneurial } \\
\text { sustainability }\end{array}$ & 0.255 & 0.039 & 6.532 & $* * *$ & Accepted \\
\hline 4 & Human relations & $\rightarrow$ & $\begin{array}{c}\text { Entrepreneurial } \\
\text { sustainability }\end{array}$ & 0.375 & 0.052 & 6.983 & $* * *$ & Accepted \\
\hline
\end{tabular}

Note: $\mathrm{SE}=$ standard error; $\mathrm{CR}=$ critical ratio; $p=$ significance level ${ }^{* * *} p<0.05$.

Similarly, the values ( $\mathrm{SE}=0.039 ; \mathrm{CR}=6.532 ; p \leq 0.01$ ) (Figure 2 and Table 7 ) confirmed a significant impact of behavior factor on entrepreneurial sustainability. Therefore, H3 
was accepted by the data. In the last, the results demonstrated a significant and positive association between human relations and entrepreneurial sustainability. Therefore, $\mathrm{H} 4$ was also accepted (SE $=0.052 ; \mathrm{CR}=6.983 ; p \leq 0.01$ ) (Figure 2 and Table 7).

\section{Discussion and Conclusions}

In today's society, the public becomes conscious regarding the requirements of the activities responsible for faster entrepreneurship by confirming environmental sustainability. In the last few years, the researchers have researched sustainable entrepreneurship, even though the debate is carried out in this perspective. To continue such a journey, we proposed investigating the aspects that substantially influence entrepreneurial sustainability in small and medium-sized enterprises of Pakistan. To attain the objective, we developed a conceptual framework in which a conceptual model and a few hypotheses were developed for investigation.

Regarding the H1, SEM results stated a positive and significant impact of environment/surroundings on entrepreneurial sustainability. These positive associations have concurred with Parrish and Foxon [53], and Belz and Binder [61] confirmed the same associations. Thus, the positive outcomes may be achieved due to a relationship of environment and surroundings factors with the fortification of the health and the well-being of the public. Instantaneously, these factors are also associated with social well-being. Therefore, sustainable entrepreneurship may positively impact structural social revolutions for promoting sustainable technologies related to sustainable creativities. Besides, in environment factors education was also connected to examine the change among the respondents. The organizational and institutional initiatives were added for exploring entrepreneurship sustainability.

With regard to $\mathrm{H} 2$, that is accepted by the data. These results are also in line with numerous scholars, such as Florea et al. [54] and Soto-Acosta et al. [64]. Thus, it assured that the business factors including job satisfaction, business management, and profits provide the maximum economic and social benefits [64] to the entrepreneurs who provide satisfaction of work, pay, type of work, as well as job security [55]. The entrepreneurs also showed gratification from efficient business management concerning strategy, organization, and control of the companies' resources to make the most profit and social advantage $[10,63,64]$.

The study also underlined a positive and significant impact of behavior factor on entrepreneurship sustainability (H3 supported). A noteworthy contribution of pro-social motivation, ethics, leadership, intelligence, competition, self-efficacy, and intrinsic motivation was observed correctly towards sustainable entrepreneurship for the variable. Sustainable entrepreneurship is determined by the people's personal and psychological dynamics, which are undertaking sustainable activities. Thus, the findings are supported by the previous studies by Shane and Venkataraman [66] and Mueller and Dato-on [58].

Lastly, the study confirmed a positive and significant impact of human relations on entrepreneurship sustainability (H4 was accepted). An initial position of the measures specifies that the vital sub-criterion for the human relations measure is leadership that involves the individual and collective leadership. In such a view, the leader contributes to a communicating process whereby individuals move towards the organization's objectives [60]. In a sequel, social mindfulness also has a powerful influence on the atmosphere benchmark. Henceforth, it relates to humanizing society to increase awareness of the impacts of environmental deterioration.

A widespread perception of organizational sustainability has been covered by previous research. It sheds reflection on the three main core areas, such as environmental integrity, economic prosperity, and social sustainability. Such covers commercial success in terms of a financial asset and diversity through various trails, such as environmental protection, price, high-quality products, and services, and the social health and well-being of the affiliates of an organization. Being a multidimensional concept, it embraces economic factors in the shape of product competitiveness, profits, the protection of environmental factors and surroundings, and social factors, which reflects people's health and well-being 
protection. Simultaneously, with their objectives for enlightening the environment and progressing social wellbeing, sustainable entrepreneurship can also influence structural social renovations and encourage sustainable technologies related to such sustainable enterprises. Such an assumption imitates sustainable entrepreneurship's reputation and the necessity to classify the components that inspire sustainable entrepreneurship. The study further protracted the ideas of Patzelt and Shephard's model [10] regarding the approach of sustainable entrepreneurship. The model proposes that motivation and knowledge boosts entrepreneurship's progress, personal welfares, and generous assistance to others. Thus, in the same aspect, we proved that for improving entrepreneurship and sustainability, human and natural resources are responsible for developing service quality for as far as is conceivable. Such a model delivers satisfaction that inspires the actions essential to accomplish specific objectives-that is so that the consequence is agreeable.

In the present study, we have considered the environmental and business factors as the drivers of sustainable entrepreneurship. The objective was to create a chain of such constructs. It is employing the quantitative approach in the context of SMEs of Pakistan that may give freshness to determine relationships in sustainable entrepreneurship. The study found that environment/surroundings factors, business factors, behavioral factors, and human-related factors are the main predictors of entrepreneurial sustainability. In a sequel, the research may contribute to entrepreneurship literature, business sustainability, particularly for developing context. In today's society, individuals are raising awareness of activities that boost entrepreneurship though guaranteeing environmental sustainability. In Pakistan, positive behavior, business environment, human relationships, and eco-friendly people significantly contribute to sustainable entrepreneurship [75], while entrepreneurship development remains a holistic view and robust tool for the national development of Pakistan [76]. It develops the capacity and offers employment prospects for national progress [77]. According to Tunio et al. [78], there are several challenges and obstacles in the entrepreneurial process and financial and entrepreneurial sustainability among the youth of Pakistan. The development of entrepreneurial intention is possible through entrepreneurial feasibility and desirability. The factors, i.e., environment, behavior, and business environment, are the driving forces of sustainable entrepreneurship among potential entrepreneurs in Pakistan [79].

With the study's practice, individuals may improve the entrepreneurial operations to upgrade the environment, develop social well-being, and make gains. It is required to determine the factors that promote entrepreneurs to sustainably manage their business ventures. Such aspects of entrepreneurial sustainability are becoming increasingly important for society to create business ventures. Further, the study may be a guideline for policymakers and planners to strengthen the factors including behavioral, business, human relation, and environment to create a smooth path of sustainability in entrepreneurship. The respondents are the significant sources of sustainability in business dynamics, because sustainability in business comes through rational decision making. It evaluates and manages individuals ${ }^{\prime}$ risk and addresses many complex problems that put current and future generations at risk. Moreover, the sustainability paradigm is used to assess three main approaches that consider the social, economic, and environmental impacts of an action or decision.

In sum, our outcomes demonstrate that environment/surroundings factors, business factors, behavioral factors, and human relation factors serve as good predictors of entrepreneurial sustainability. The current study model provides the new approach by presenting that the business factors may be the "thin end of the wedge" in behavioral aspects, and mutual leadership must reinforce them and competitive intelligence and ethics, as well as job satisfaction. The outcomes also underlined that environmental factors are scarcely well thought-out by entrepreneurs in sustainable entrepreneurship. These elements may be more protuberant in entrepreneurial creativities in the country. The study would bring new insight into the SMEs sector's entrepreneurial sustainability through environmental, business, behavior, and human relation factors, particularly in developing economies. These empirical findings would help scholars in generating the theories based on the present 
robust evidence. Besides, the confirmation of these associations would further deepen and validate the reliability of the constructs to develop the theoretical frameworks.

\section{Implications, Limitations and Future Research}

In any other empirical investigations the current study may provide the benefits for further developments. The study's findings may give freshness to determine connections in the area of sustainable entrepreneurship in SMEs context. The study may be a guideline for policymakers and planners to strengthen the factors including behavioral, business, human relation, and environment to create a smooth path of sustainability in entrepreneurship.

SMEs are accepted as meaningful drivers to create employment, economic growth, business promotion, and regional development. In light of this fact, both governments and non-governmental organizations may have to initiate strategies and policies to facilitate the entrepreneurs by promoting local industries. The knowledge-based/learning economy delivers significant opportunities for environmental management. It is a practical application that enables entrepreneurs to generate new products. It would entail the continuous advancement of low key economic factors with a healthy marketplace climate of entrepreneurship. In the previous studies, investigation of entrepreneurship sustainability and its predictors provided new ideas and solutions for SMEs in several countries, including developed and developing countries. These investigations also promoted environmental management, business, ecological backgrounds, and entrepreneurial behavior, particularly in SMEs. Likewise, for Pakistan, the study would be a valuable tool in bringing environmental management in SMEs by promoting entrepreneurship, business promotion, ecological surroundings, and entrepreneurship-related behavior. The study would further guide and encourage the top management of SEMs to develop a more conducive business environment where the business activities can be more effectively developed. The study would also be supportive in creating the environmentally friendly behavior in which human relations would enjoy the achievement of healthy entrepreneurial sustainability. The study would be beneficial to tackle the SMEs challenges in terms of Pakistan's well-being and economic steadiness.

The incremental scientific output of the study provides values and knowledge. It contributes ideas regarding entrepreneurial sustainability through environmental, business, behavioral, and human relational factors. Methodologically, the study confirms these factors in a large sample size in the SMEs sector. Besides, it provides evidence of conformity and validation of multiple items through convergent validity, composite reliability, and model fitness in a developing context. With regard to incremental knowledge, it is more valuable in predicting and prone to planning regarding the sustainability of the environment.

Hence, the study has certain limitations. First, we selected the specific definitions of the terms that may rate change and situations. Therefore, interpretations of their implications may differ to such extents. Second, we applied only a survey questionnaire as the primary tool for collecting the information. This method may not offer hidden facts about the sustainability of entrepreneurship. We employed a five-point Likert scale. The usage of such a scale may not provide a clear-cut behavior/reply of the entrepreneurs. As compared to the Likert scale, a dichotomous scale is easier to understand for the responses. Third, this study is limited to cross-sectional data and respondents (entrepreneurs/who started their business in SMEs). Finally, the study investigated a small sample that bounds the generalization of the drawn conclusions.

We employed cross-sectional data for investigating the entrepreneurial sustainability in SMEs context. In future, more longitudinal studies are required in other sectors where entrepreneurs are actively engaged. We developed a model from business, environmental, behavioral, and human relational factors. However, other factors, such as psychological, social, and economic factors in future studies may envisage another multi-item framework directing the behavioral, social, and economic aspects. The same model may be tested on larger samples or in the perspective of specific business sectors in the future. Thus, it may 
fill the colors in the analysis as more accurate and more evident from the standpoint of such a field as art. Lastly, the same model may be tested in other developing contexts, as well as in a European setting, to make more generalizations.

Author Contributions: Conceptualization, N.A.A.A. and B.A.S.; methodology, B.A.S.; software, B.A.S.; validation N.S., B.A.S. and N.A.A.A.; formal analysis, B.A.S.; investigation, B.A.S.; resources, N.S.; data curation, N.S.; writing — original draft preparation, N.A.A.A., B.A.S. and N.S.; writingreview and editing, N.A.A.A.; visualization, N.S.; supervision, N.A.A.A.; project administration, N.A.A.A.; funding acquisition, N.A.A.A., B.A.S. and N.S. All authors have read and agreed to the published version of the manuscript.

Funding: This work was supported by the Deanship of Scientific Research, Vice Presidency for Graduate Studies and Scientific Research, King Faisal University, Saudi Arabia [Project No. GRANT78].

Conflicts of Interest: The authors declare no conflict of interest.

\section{References}

1. York, J.G.; Venkataraman, S. The entrepreneur-environment nexus: Uncertainty, innovation, and allocation. J. Bus. Ventur. 2010, 25, 449-463. [CrossRef]

2. Shepherd, D.A.; Patzelt, H. The new field of sustainable entrepreneurship: Studying entrepreneurial action linking "What is to be sustained" with "What is to be developed. Entrep. Theory Pract. 2011, 35, 137-163. [CrossRef]

3. Dean, T.J.; McMullen, J.S. Toward a theory of sustainable entrepreneurship: Reducing environmental degradation through entrepreneurial action. J. Bus. Ventur. 2007, 22, 50-76. [CrossRef]

4. Cohen, B.; Winn, M.I. Market imperfections, opportunity and sustainable entrepreneurship. J. Bus. Ventur. 2007, 22, $29-49$. [CrossRef]

5. Hockerts, K.; Wustenhagen, R. Greening Goliaths versus emerging Davids- theorizing about the role of incumbents and new entrants in sustainable entrepreneurship. J. Bus. Ventur. 2010, 25, 481-492. [CrossRef]

6. Kuckertz, A.; Wagner, M. The influence of sustainability orientation on entrepreneurial intentions-investigating the role of business experience. J. Bus. Ventur. 2010, 25, 524-539. [CrossRef]

7. Parrish, B.D. Sustainability-driven entrepreneurship: Principles of organization design. J. Bus. Ventur. 2010, 25, 510-523. [CrossRef]

8. Muñoz, P.; Dimov, D. The call of the whole in understanding the development of sustainable ventures. J. Bus. Ventur. 2015, 30, 632-654. [CrossRef]

9. Hamann, R.; Smith, J.; Tashman, P.; Marshall, R.S. Why do SMEs go green? An analysis of wine firms in South Africa. Bus. Soc. 2017, 56, 23-56. [CrossRef]

10. Tur-Porcar, A.; Roig-Tierno, N.; Mestre, A.L. Factors affecting entrepreneurship and business sustainability. Sustainability 2018, 10, 452. [CrossRef]

11. Horisch, J. Entrepreneurship as facilitator for sustainable development? Editorial for the special issue "Advances in sustainable entrepreneurship". Adm. Sci. 2016, 6, 4. [CrossRef]

12. Hisrich, R.D.; Peters, M.P.; Shepherd, D.A. Entrepreneurship, 9th ed.; McGraw Hill: New York, NY, USA, 2013.

13. Hall, J.K.; Daneke, G.A.; Lenox, M.J. Sustainable development and entrepreneurship: Past contributions and future directions. J. Bus. Ventur. 2010, 25, 439-448. [CrossRef]

14. Yang, Y.; Chen, X.; Gu, J.; Fujita, H. Alleviating financing constraints of SMEs through supply chain. Sustainability 2019, 11, 673. [CrossRef]

15. Soomro, B.A.; Shah, N.; Mangi, S. Factors affecting entrepreneurial leadership in small and medium enterprises (SMEs) of Pakistan: Empirical evidence. World J. Entrep. Manag. Sustain. Dev. 2019, 15, 31-44. [CrossRef]

16. Qureshi, S.; Aftab, E. KoldKraft Pakistan: An Entrepreneurial Journey. Asian J. Manag. Cases 2015, 12, 29-41. [CrossRef]

17. Soomro, B.A.; Ghumro, I.A.; Shah, N. Green entrepreneurship inclination among younger generation: An avenue towards a green economy. Sustain. Dev. 2019, 28, 585-594. [CrossRef]

18. Tachiwou, A.M. Infrastructure development and economic growth in Togo. Int. J. Econ. Financ. 2008, 3, 131-138. [CrossRef]

19. Koe, W.; Omar, R.; Sa'ari, J.R. Factors influencing propensity to sustainable entrepreneurship of SMEs in Malaysia. Procedia-Soc. Behav. Sci. 2015, 172, 570-577. [CrossRef]

20. Peralta, A.; Rubalcaba, L. How governance paradigms and other drivers affect public managers' use of innovation practices. A PLS-SEM analysis and model. Mathematics 2021, 9, 1055. [CrossRef]

21. Sarabia, M.; Crecente, F.; Castano, R. Why do sustainable mergers fail to manage entrepreneurship? Sustainability 2019, 11, 525. [CrossRef]

22. Uhlaner, L.M.; Goor-Balk, H.J.M.; Masurel, E. Family business and corporate social responsibility in a sample of Dutch firms. J. Small Bus. Enterp. Dev. 2004, 11, 186-194. [CrossRef]

23. Dionco-Adetayo, E. Determinant of small firms' entrepreneurial success in developing economy. In Nigeria; Obafemi Awolowo University: Ile-Ife, Nigeria, 2004; pp. 1-17. 
24. Maseko, N.; Manyanin, O.; Chiriserin, L.; Tsakea, S.; Mugogo, P.C.; Chazuza, T.; Muntengezanwa, M. An analysis of the impact of targeted government support on SMEs growth and development in Zimbabwe: A survey of Mashonaland central province. J. Res. Int. Bus. Manag. 2011, 2, 051-059.

25. Rahman, H.; Singh, H.R. Entrepreneurial support and its levels of success. Glob. J. Res. Anal. 2014, 3, 63-65.

26. Ras, P.J.; Vermeulen, W.J.V. Sustainable production and the performance of South African entrepreneurs in a global supply chain. The case of South African table grape producers. Sustain. Dev. 2009, 17, 325-340. [CrossRef]

27. Mehtap, S.; Pellegrini, M.M.; Caputo, A.; Welsh, D.H.B. Entrepreneurial intentions of young women in the Arab world: Sociocultural and educational barriers. Int. J. Entrep. Behav. Res. 2017, 23, 880-902. [CrossRef]

28. Mahjoub, L.B.; Amara, I. The impact of cultural factors on shareholder governance and environmental sustainability: An international context. World J. Sci. Technol. Sustain. Dev. 2020, 17, 367-385. [CrossRef]

29. Abu Bakar, A.R.; Ahmad, S.Z.; Wright, N.S.; Skoko, H. The propensity to business startup: Evidence from Global Entrepreneurship Monitor (GEM) data in Saudi Arabia. J. Entrep. Emerg. Econ. 2017, 9, 263-285. [CrossRef]

30. Alayis, M.M.; Abdelwahed, N.A.; Atteya, N. Impact of social networking sites' use on entrepreneurial intention among undergraduate business students: The case of Saudi Arabia. Int. J. Entrep. 2018, 22, 1-18.

31. Basri, W.S.M.; Siam, M.R.A. Social media and corporate communication antecedents of SME sustainability performance: A conceptual framework for SMEs of Arab world. J. Econ. Adm. Sci. 2019, 35, 172-182. [CrossRef]

32. Aljuwaiber, A. Entrepreneurship research in the Middle East and North Africa: Trends, challenges, and sustainability issues. J. Entrep. Emerg. Econ. 2021, 13, 380-426. [CrossRef]

33. Donna, M.; Lucy, M.; Paul, M.; Marius, C. Going above and beyond: How sustainability culture and entrepreneurial orientation drive social sustainability supply chain practice adoption. Supply Chain Manag. Int. J. 2015, 20, 434-454.

34. Hosseininia, G.; Ramezani, A. Factors influencing sustainable entrepreneurship in small and medium-sized enterprises in Iran: A case study of food industry. Sustainability 2016, 8, 1010. [CrossRef]

35. Amankwah-Amoah, J.; Danso, A.; Adomako, S. Entrepreneurial orientation, environmental sustainability and new venture performance: Does stakeholder integration matter? Bus. Strategy Environ. 2018, 28, 79-87. [CrossRef]

36. Randerson, K.; Bettinelli, C.; Fayolle, A.; Anderson, A. Family entrepreneurship as a field of research: Exploring its contours and contents. J. Fam. Bus. Strategy 2015, 6, 143-154. [CrossRef]

37. Nikabadi, M.S.; Jafarian, A. Framework for selecting an appropriate e-business model in SMEs. Int. J. E-Bus. Dev. 2012, 2, 86-96.

38. Ayyagari, M.; Bech, T.; Demirguc-Kunt, A. Small and medium enterprise across the globe. Small Bus. Econ. 2007, $29,415-434$. [CrossRef]

39. Wattanapinyo, A.; Mol, A.P.J. Ecological modernization and environmental policy reform in Thailand: The case of food processing SMEs. Sustain. Dev. 2013, 21, 309-323. [CrossRef]

40. Ukko, J.; Saunila, M.; Rantala, T.; Havukainen, J. Sustainable development: Implications and definition for open sustainability. Sustain. Dev. 2019, 27, 321-336. [CrossRef]

41. Davies, A.R. Does sustainability count? Environmental policy, sustainable development and the governance of grassroots sustainability enterprise in Ireland. Sustain. Dev. 2009, 17, 174-182. [CrossRef]

42. Saqib, Z.; Khan, M.; Michael, M. Striving for self-sustainability: Case of a Pakistani NGO. Asian J. Manag. Cases 2015, 14, 38-48. [CrossRef]

43. Walley, E.; Taylor, D. Opportunists, champions, mavericks? A typology of green entrepreneurs. Greener Manag. Int. 2002, 38, 31-35. [CrossRef]

44. Mazzarol, T.; Volery, T.; Doss, N.; Thein, V. Factors influencing small business start-ups. Int. J. Entrep. Behav. Res. 1999, 5, 48-63. [CrossRef]

45. Gasbarro, F.; Rizzi, F.; Frey, M. Sustainable institutional entrepreneurship in practice: Insights from SMEs in the clean energy sector in Tuscany (Italy). Int. J. Entrep. Behav. Res. 2018, 24, 476-498. [CrossRef]

46. Sinha, T.N. Human factors in entrepreneurship effectiveness. J. Entrep. 1996, 5, 23-29. [CrossRef]

47. Young, W.; Tilley, F. Can businesses move beyond efficiency? The shift toward effectiveness and equity in the corporate sustainability debate. Bus. Strategy Environ. 2006, 15, 402-415. [CrossRef]

48. Vuorio, A.M.; Puumalainen, K.; Fellnhofer, K. Drivers of entrepreneurial intentions in sustainable entrepreneurship. Int. J. Entrep. Behav. Res. 2018, 24, 359-381. [CrossRef]

49. Rajasekaran, B. Sustainable entrepreneurship: Past researches and future directions. J. Entrep. Manag. 2013, 2, $20-27$.

50. Loucks, E.S.; Martens, M.L.; Cho, C.H. Engaging small- and medium-sized businesses in sustainability. Sustain. Account. Manag. Policy J. 2010, 1, 178-200.

51. Rohra, C.I.; Panhwar, I.A. The role of SMEs towards exports in Pakistan economy. Aust. J. Basic Appl. Sci. 2009, 3, 1070-1082.

52. Ahmed, I.; Shahzad, A.; Umar, M.; Khilji, B.A. Information technology and SMEs in Pakistan. Int. Bus. Res. 2010, 3, 237-240. [CrossRef]

53. Parrish, B.D.; Foxon, T.J. Sustainability entrepreneurship and equitable transitions to a low-carbon economy. Greener Manag. Int. 2006, 55, 47-62. [CrossRef]

54. Florea, L.; Cheung, Y.H.; Herndon, N.C. For all good reasons: Role of values in organizational sustainability. J. Bus. Ethics 2013, 114, 393-408. [CrossRef]

55. Omorede, A.; Thorgren, S.; Wincent, J. Entrepreneurship psychology: A review. Int. Entrep. Manag. J. 2015, 11, 743-768. [CrossRef] 
56. Haynie, M.; Shepherd, D.A. A measure of adaptive cognition for entrepreneurship research. Entrep. Theory Pract. 2009, 33, 695-714. [CrossRef]

57. Baron, R.A.; Tang, J. The role of entrepreneurs in firm-level innovation: Joint effects of positive affect, creativity, and environmental dynamism. J. Bus. Ventur. 2011, 26, 49-60. [CrossRef]

58. Mueller, S.L.; Dato-on, M.C. A cross cultural study of gender-role orientation and entrepreneurial self-efficacy. Int. Entrep. Manag. J. 2013, 9, 1-20. [CrossRef]

59. Choongo, P.; Van Burg, E.; Paas, L.J.; Masurel, E. Factors influencing the identification of sustainable opportunities by SMEs: Empirical evidence from Zambia. Sustainability 2016, 8, 81. [CrossRef]

60. Yitshaki, R.; Kropp, F. Motivations and opportunity recognition of social entrepreneurs. J. Small Bus. Manag. 2016, 54, 546-565. [CrossRef]

61. Belz, F.M.; Binder, J.K. Sustainable entrepreneurship: A convergent process model. Bus. Strategy Environ. 2017, 26, 1-17. [CrossRef]

62. Manz, C.C.; Skaggs, B.C.; Pearce, C.L.; Wassenaar, C.L. Serving one another: Are shared and self-leadership the keys to service sustainability? J. Organ. Behav. 2015, 36, 607-612. [CrossRef]

63. Rosalinde, J.A.; Woolthuis, K. Sustainable entrepreneurship in the Dutch construction industry. Sustainability $2010,2,505-523$.

64. Soto-Acosta, P.; Cismaru, D.; Vatamanescu, E.; Ciochina, R.S. Sustainable entrepreneurship in SMEs: A business performance perspective. Sustainability 2016, 8, 342. [CrossRef]

65. Patzelt, H.; Shepherd, D.A. Recognizing opportunities for sustainable development. Entrep. Theory Pract. 2011, 35, 631-652. [CrossRef]

66. Shane, S.; Venkataraman, S. The promise of entrepreneurship as a field of research. Acad. Manag. Rev. 2000, 25, 217-226. [CrossRef]

67. Meek, W.R.; Pacheco, D.F.; York, J.G. The impact of social norms on entrepreneurial action: Evidence from the environmental entrepreneurship context. J. Bus. Ventur. 2010, 25, 493-509. [CrossRef]

68. O'Neill, G.D.; Hershauer, J.C.; Golden, J.S. The cultural context of sustainability entrepreneurship. Greener Manag. Int. 2006, 55, 33-46. [CrossRef]

69. Norton, C.L. Social work and the environment: An eco-social approach. Int. J. Soc. Welf. 2012, 21, 299-308. [CrossRef]

70. Compeau, D.; Higgins, C.A.; Huff, S. Social cognitive theory and individual reactions to computing technology: A longitudinal study. MIS Q. 1999, 23, 145-158. [CrossRef]

71. Ramayah, T.; Lee, J.W.C.; Boey, J.C.I. Network collaboration and performance in the tourism sector. Serv. Bus. 2011, 5, 411-428. [CrossRef]

72. Marsh, H.W.; Hocevar, D. Application of confirmatory factor analysis to the study of self-concept: First- and higher order factor models and their invariance across groups. Psychol. Bull. 1985, 97, 562-582. [CrossRef]

73. Hair, J.; Black, W.; Babin, B.; Anderson, R.; Tatham, R. Multivariate Data Analysis, 6th ed.; Pearson Prentice Hall, Pearson Education, Inc.: Upper Saddle River, NJ, USA, 2006.

74. Yvette, R.; Felix, M. Structural equation modeling. J. Travel Tour. Mark. 2007, 21, 41-71.

75. Soomro, B.A.; Almahdi, H.K.; Shah, N. Perceptions of young entrepreneurial aspirants towards sustainable entrepreneurship in Pakistan. Kybernetes 2021, 50, 2134-2154. [CrossRef]

76. Chemin, M. Entrepreneurship in Pakistan: Government policy on SMEs, environment for entrepreneurship, internationalization of entrepreneurs and SMEs. Int. J. Bus. Glob. 2010, 5, 238-247. [CrossRef]

77. Idress, F.; Hassan, H. Entrepreneurship's role in enhancing the productivity and sustainability of Pakistan. Glob. Reg. Rev. 2019, 4, 376-383.

78. Tunio, M.N.; Chaudhry, I.S.; Shaikh, S.; Jariko, M.A.; Brahmi, M. Determinants of the sustainable entrepreneurial engagement of youth in developing country-An empirical evidence from Pakistan. Sustainability 2021, 13, 7764. [CrossRef]

79. Sher, A.; Abbas, A.; Mazhar, S.; Azadi, H.; Lin, G. Fostering sustainable ventures: Drivers of sustainable start-up intentions among aspiring entrepreneurs in Pakistan. J. Clean. Prod. 2020, 262, 121269. [CrossRef] 